\title{
The Impact of Governance Mechanism of Financial Listed Companies on the Pay and the Pay-Performance Sensitivity of Executives
}

\author{
Sen Wang ${ }^{1} \&$ Feng Liu ${ }^{2}$ \\ ${ }^{1}$ School of International Business, Jinan University, Zhuhai, China \\ ${ }^{2}$ School of Economics, Jinan University, Guangzhou, China \\ Correspondence: Feng Liu, School of Economics, Jinan University, Guangzhou, 510632, China. \\ E-mail:2453334669@qq.com
}

Received: January 7, 2018

doi:10.5539/ijbm.v13n3p233

\author{
Accepted: February 10, $2018 \quad$ Online Published: February 25, 2018 \\ URL: https://doi.org/10.5539/ijbm.v13n3p233
}

\begin{abstract}
The corporate governance mechanism is very important to solve the principal-agent problem effectively. Based on the particularity of the financial industry, this paper uses the panel data of 45 listed companies in China's financial industry from 2007 to 2015, the empirical results show that the degree of ownership concentration, the duality of CEO and chairman of the board and the independent directors proportion have a significant negative impact on executive pay, and the size of the board of supervisors has no marked impact on executive pay. The degree of ownership concentration has a significant positive impact on the pay-performance sensitivity, and the duality of CEO and chairman of the board, the independent directors proportion and the size of the board of supervisors have a significant negative impact on the pay-performance sensitivity. For the listed companies in the financial sector, they should pay attention to the executive pay disclosure system, the board of supervisors governance mechanism and the independent director system. We can use the degree of ownership concentration to improve the pay-performance sensitivity, and make corporate governance more effective.
\end{abstract}

Keywords: finance, governance mechanism, executive pay, pay-performance sensitivity

\section{Introduction}

The incentive mechanism and the constraint mechanism are two "magic weapon" to solve the problem of principal-agent problem in modern enterprises. In order to make executives and clients act in line with their goals, the former mechanism adopts the method of pay and enterprise performance, which can effectively prevent moral hazard of the manager, and make his behavior consistent with the principle of maximizing the interests of shareholders. The latter mechanism is designed to strengthen the supervision and control of executives through the function of the internal organs of the company, and reduce the possibility that executives can use their power for their own profit. Therefore, how to exert the effectiveness of corporate governance mechanism is the focus of scholars.

In 2017, the National Financial Work Conference proposed three tasks. Among them, deepening the financial reform pointed out that the modern financial enterprise system should be improved, the incentive and restraint should be reasonable. The fundamental purpose of finance is to serve the real economy, and executive pay in the finance industry have received widespread attention over real enterprises. In terms of corporate governance, financial companies have high leverage ratios. Because of their unique high risk, financial companies have been regulated by the relevant departments. This high liability and regulatory of financial firms has further influenced the sensitivity between executive pay and performance. Improving the internal governance mechanism of financial companies and promoting pay incentive mechanism are conducive to creating a sound financial environment for the development of the real economy. To further promote the virtuous circle of economy and finance. On the other hand, the country advancing the reform of the financial industry, standardizing the securities market, and expanding Internet finance, it is a process from financial repression to financial freedom in our country. Therefore, this paper takes the data of 45 listed companies in the financial industry from 2007 to 2015, and studies the impact of governance mechanism of financial listed companies on the pay and the pay-performance sensitivity of executives. 


\section{Literature Review}

\subsection{The Influence of Corporate Governance Mechanism on Executive Pay}

Domestic and foreign scholars come to a similar conclusion about the ownership concentration and executive pay: there is a negative correlation between them. The empirical results of Firth (1999), Tang Guoqiong and Hu Maoli (2012) show that the higher the concentration of ownership, the lower the executive pay. Ko and Chan (2014) demonstrate the correlation between ownership concentration and market performance through empirical research, and there is a positive correlation between ownership concentration and market performance sensitivity.

Many scholars have found that in the enterprise, the duality of CEO and chairman of the board will exert some influence on the establishment of the pay system. Cyert, Kang and Kumar (2002), Fahlenbrach (2009) consider that the duality of CEO and chairman of the board has a significant positive impact on executive pay, and Cyert from both theoretical and empirical considers that ordinary shareholders ownership have obvious positive effects on executive pay. Conyon and Peck (1998) find that there is no significant correlation between the duality of $\mathrm{CEO}$ and chairman of the board in the enterprise and executive pay. The conclusions drawn by domestic scholars are more unified. Zhou Jianbo and Sun Jusheng (2003), Zhang Biwu and Shi Jintao (2005), Li Weian, Liu Xuangang and Chen Jinghan (2010) and Gao Qi (2015) find that there is a positive relationship between them.

Scholars study find that the independent directors proportion has a certain impact on executive pay. Boyd (1994) through empirical analysis conclude that there is a negative correlation between the independent directors proportion and executive pay. Cordeiro and Veliyath (2000), Zhang Biwu and Shi Jintao (2007), Yuan Chunsheng and Tang Songlian (2015) show that there is a positive correlation between the proportion of independent directors and executive pay. Using a dynamic panel model, Wang Changrong (2015) finds that when managers have more power than the board of directors, internal governance can not constrain executives and make executives pay higher.

The impact of the size of the board of supervisors on executive pay has yet to reach a consensus. Su Fangguo (2011) comes to the conclusion that the larger the board of supervisors, the lower the executive pay when studying domestic listed companies. Han Tianxi (2012) argues that when the board of supervisors is over-sized, its supervisory efficiency will be reduced, resulting in a higher executive pay level. According to the results of Yao Lushi and Xu Xin (2012), the remuneration of innovative enterprise executives is positively correlated with the size of the supervisory board.

\subsection{The Impact of Corporate Governance Mechanism on the Pay-performance Sensitivity}

Yermack (1996) studies the relationship between the size of the US board of directors and the pay-performance sensitivity and finds that there is a significant negative impact between them. Hartzell and Starks (2003) study the data of 1914 listed companies from 1992 to 1997 and find that ownership concentration has a significant positive impact on the pay-performance sensitivity. Hwang and Kim (2009) conduct a study of Fortune 100 companies in 2005 and find that the proportion of independent directors can increase the pay-performance sensitivity.

Xiong Fenghua and Peng Jue (2012) show that companies with high executive power have low pay-performance sensitivity. The study by Tang Guoqiong and Hu Maoli (2012) find that non-state-owned enterprises have a higher pay-performance sensitivity than state-owned enterprises and the proportion of independent directors is positively related to the pay-performance sensitivity. Liu Xing and Xu Guangwei (2012) conduct a research on state-owned listed companies. The results show that the power in the hands of supervisors has a significant impact on the contract of pay, which in turn leads to downward rigidity and upward flexibility of remuneration. Wu Xiancong (2015) shows that independent institutional investors can have a positive impact on corporate governance, not only improving executive's pay-performance sensitivity but also reducing executives' private earnings. Liu Min (2015) finds that the concentration of ownership, the proportion of independent directors and the size of the board of directors are positively correlated with executive's pay-performance sensitivity. The size of the company is negatively correlated with the pay-performance sensitivity. Zhang Xuegong and Liu Wei (2016) study the cross-sectional data of listed companies in China. The ownership concentration and separation of two posts have a negative impact on executive pay. The proportion of remuneration committee and the proportion of independent directors have a positive impact on executive pay. Under different performance conditions, the impact of corporate governance on executive pay and the pay-performance sensitivity is asymmetrical. 


\subsection{Related Research on Executive Pay and the Pay-Performance Sensitivity of Financial Listed Companies}

Huang Jun, Jiang Yingge and Tian Bin (2010) study the influencing factors of executive pay of 27 listed companies in the financial industry in China. They find that ownership concentration and the size of the company are correlated with executive pay. The performance of the company, the proportion of independent directors and the board size are't correlated with executive pay. Huang Ping and Chen Li (2014) study on China's Listed Banks: State-owned shares, shareholding ratio and the size of the board of supervisors have a negative impact on executive pay. Zhao Huawei (2015) conducts a study on the data of listed banks in China and find that the expansion of the company's size is conducive to executives to better perform their talents and get higher pay. Man Yuanyuan, Yang Yuesheng and Sun Wei (2015) argue that the market share is not significant for the improvement of commercial banking performance while the change of asset scale model is the major factor for the improvement of banking performance.

Gilson and Vetsuypens (1993) find a negative relationship between the CEO's pay-performance sensitivity and the company's financial position.

John and Qian (2003) think that the special debt ratio of the banking industry makes the pay-performance sensitivity of the banking CEO higher than that of the manufacturing industry. Zhao Huawei (2015) on the study of China's listed banks finds that managerial talent has a positive relationship with the pay-performance sensitivity, and management power has a negative impact on the pay-performance sensitivity.

In summary, the researches on the impact of corporate governance on pay and the pay-performance sensitivity mainly focus on the concentration of ownership, the duality of CEO and chairman of the board, the proportion of independent directors, the size of the board of supervisors and the size of the board of directors. Compared with foreign countries, the domestic research started relatively late, and the researces mainly focus on the previous years, timely and up-to-date research is needed. With the liberalization of the financial industry and the increasing attention paid to executive pay in recent years, the latest research needs to be made timely. In the past, the vast majority of the research focused on listed companies as a whole. The research on the financial industry was also dominated by banks and few studies on the financial industry as a whole. Most of the studies on banks focus on other aspects such as leverage ratio and business risk, etc.. There are few researches on corporate governance mechanism. Due to the difference between financial companies and manufacturing companies, and the actual economic and financial conditions have undergone great changes, it is necessary to systematically study the effects of the governance mechanism of financial listed companies on executive pay and the pay-performance sensitivity.

\section{Theoretical Analysis and Research Hypotheses}

Principal-agent Theory: the principal-agent relationships formed in the context of separation of ownership and management. If you want to reduce the agency costs, we must link the agency's revenue with the performance of the enterprise and induce it to maximize the value of the enterprise. At present, many western countries make executive pay based on principal-agent theory.

Corporate Governance Theory: Under the company system, there are many interests including the relationship among directors, shareholders and executives. The development of a business is influenced by the interests of theirs. It is the core problem of corporate governance to protect the interests of all parties, solve agency problems and reduce agency cost. In order to solve the agency problem, it needs the combination of internal and external governance. Internal governance refers to the construction and structure of the company's internal management structure. External governance is coordinated by market governance and public governance.

\subsection{Ownership Concentration}

When the ownership concentration is high, it is convenient for major shareholders to supervise operators. However, if the shareholding is relatively fragmented, a single minority shareholder may lose the motivation to supervise due to the high cost. The conclusions from the previous studies are basically the same. Enterprises with high concentration of ownership will be more effective in supervising the executives, reducing the opportunities for executives to seek higher salaries, and also getting the relationship between executive pay and firm performance closer together. Based on this, we put forward the hypothesis:

Hypothesis 1a: There is a negative correlation between ownership concentration and executive pay.

Hypothesis $1 \mathrm{~b}$ : There is a positive correlation between ownership concentration and the pay-performance sensitivity. 


\subsection{The Duality of CEO and Chairman of the Board}

The remuneration of executives of listed companies is decided by the board of directors. When the duality of CEO and chairman of the board, the effectiveness of the board of directors will decline, which may result in the over-pay of senior management and reduce the effectiveness of the contract of performance-based remuneration. Some studies have suggested that in order to improve the independence of the board of directors, it is necessary to separate the roles of CEO and chairman of the board. Based on this, we put forward the hypothesis:

Hypothesis 2a: There is a positive correlation between the duality of CEO and chairman of the board and executive pay.

Hypothesis $2 \mathrm{~b}$ : There is a negative correlation between the duality of CEO and chairman of the board and the pay-performance sensitivity

\subsection{The Proportion of Independent Directors}

Independent directors, as members of the board of directors, can enhance the independence of the board of directors as well as the effectiveness of supervision and governance. Generally speaking, a high proportion of independent directors can improve the efficiency of corporate governance and make the pay-performance sensitivity is stronger, namely due to the supervision being more effective, its pay levels may be lower. Based on this, we put forward the hypothesis:

Hypothesis 3a: There is a negative correlation between the proportion of independent directors and executive pay.

Hypothesis $3 \mathrm{~b}$ : There is a positive correlation between the proportion of independent directors and the pay-performance sensitivity.

\subsection{The Size of the Supervisory Board}

There has been no consensus on the impact of the supervisory board on executive pay and the pay-performance sensitivity. In theory, the board of supervisors, as a specialized supervisory body, can prevent executives from abusing their power to make self-made remuneration, while the board of supervisors can indirectly influence the effectiveness of remuneration incentives. However, some scholars also find that the scale is too large, it can also cause the internal inefficiency of the board of supervisors, thus affecting the effectiveness of its supervision. Based on this, we put forward the hypothesis:

Hypothesis 4a: There is a negative correlation between the size of the board of supervisors and executive pay.

Hypothesis 4b: There is a positive correlation between the size of the board of supervisors and the pay-performance sensitivity.

\section{Empirical Research}

Collect data from financial companies through channels such as CSMAR and Wind database, and supplement relevant data through the official websites of companies. Sort out the data of 2007-2015 listed companies in the financial industry.

\subsection{Variable Selection}

\subsubsection{Explained Variable}

Pay level variable (COMP): the total pay of the top three executives in China's financial industry.

\subsubsection{Explanatory Variables}

(1) Corporate performance variable:

Rate of Return on Common Stockholders' Equity(ROE).

(2) Corporate governance mechanism variables:

Ownership concentration (OC), shareholding of largest shareholder.

The duality of CEO and chairman of the board (BOTH), if the chairman of the board and CEO are held by one person, then 1 , otherwise 0 .

The proportion of independent directors (OUT), the proportion of independent directors to the total number of directors.

The size of the board of supervisors (SS), the total number of supervisors in the board of supervisors. 


\subsubsection{Control Variables}

(1) Company size (SIZE), the common logarithm of the company's total assets.

(2) Company growth rate (RGR), revenue growth rate.

Table 1. Variable definition

\begin{tabular}{|c|c|c|c|}
\hline Variable types & Variable name & $\begin{array}{l}\text { Variable } \\
\text { symbol }\end{array}$ & Variable meaning \\
\hline \multirow[t]{5}{*}{$\begin{array}{l}\text { Explained } \\
\text { variable }\end{array}$} & Pay level variable & COMP & $\begin{array}{l}\text { The total pay of the top three executives in China's } \\
\text { financial industry }\end{array}$ \\
\hline & Corporate performance variable & ROE & Rate of return on common stockholders' equity \\
\hline & Ownership concentration & $\mathrm{OC}$ & Shareholding of Largest Shareholder \\
\hline & $\begin{array}{l}\text { The duality of CEO and } \\
\text { chairman of the board }\end{array}$ & BOTH & $\begin{array}{l}\text { If the chairman of the board and CEO are held by one } \\
\text { person, then } 1 \text {, otherwise } 0\end{array}$ \\
\hline & $\begin{array}{l}\text { The proportion of independent } \\
\text { directors }\end{array}$ & OUT & $\begin{array}{l}\text { The proportion of independent directors to the total } \\
\text { number of directors }\end{array}$ \\
\hline \multirow{2}{*}{$\begin{array}{l}\text { Explanatory } \\
\text { variables }\end{array}$} & $\begin{array}{l}\text { The size of the board of } \\
\text { supervisors }\end{array}$ & SS & The common logarithm of the company's total assets \\
\hline & Company size & SIZE & The common logarithm of the company's total assets \\
\hline Control variables & Company growth rate & RGR & Revenue growth rate \\
\hline
\end{tabular}

\subsection{Regression Model}

This paper makes an empirical analysis on the influence of the corporate governance mechanism of listed companies in China on executive pay and the pay-performance sensitivity. The model is as follows:

The impact of corporate governance mechanism on executive pay.

$$
\ln (\operatorname{COMP} \quad)_{i}=\beta_{0}+\beta_{1} R O E+\beta_{2} O C+\beta_{3} B O T H+\beta_{4} O U T+\beta_{5} S S+\beta 6 Y_{i}+\varepsilon_{i}
$$

Among them, $Y_{\mathrm{i}}$ is SIZE, RGR (equation 1).

The impact of corporate governance mechanisms on the pay-performance sensitivity.

$$
\ln (\operatorname{COMP} \quad)_{i}=\beta_{0}+\beta_{1} R O E i+\beta_{2}\left(R O E i * X_{i}\right)+\beta_{3} Y_{i}+\varepsilon_{i}
$$

Among them, $X_{\mathrm{i}}$ is OC (equation 2), BOTH(equation 3), OUT(equation 4), SS(equation 5), $\mathrm{Y}_{\mathrm{i}}$ is SIZE, RGR. When studying the impact of an explanatory variable on the interpreted variables, the explanatory variable is substituted into the model.

\subsection{Descriptive Statistical Analysis}

Table2. Descriptive Statistics Analysis

\begin{tabular}{llllll}
\hline Metric & Average & Maximum & Minimum & Median & Standard deviation \\
\hline $\ln ($ comp $)$ & 14.39 & 17.67 & 10.92 & 14.51 & 1.00 \\
roe & 0.14 & 2.64 & -4.62 & 0.16 & 0.31 \\
oc & 0.27 & 0.68 & 0.05 & 0.24 & 0.16 \\
both & 0.07 & 1.00 & 0.00 & 0.00 & 0.25 \\
out & 0.36 & 0.60 & 0.17 & 0.35 & 0.04 \\
ss & 6.79 & 13.00 & 2.00 & 7.00 & 2.66 \\
$\ln ($ size $)$ & 26.24 & 30.73 & 19.66 & 26.32 & 2.48 \\
rgr & 0.29 & 3.55 & -1.37 & 0.20 & 0.54 \\
\hline
\end{tabular}

Data sources: Wind database, Cathay Pacific database, the company's annual report finishing. 
From table 2 we can see that China's financial industry executives have very different pay. The top three executives received a maximum total pay of 47,331,700 yuan, the lowest is only 55,300 yuan. There is a big difference in total return on assets, the highest is 2.64 , the lowest is -4.62 . The average value of equity concentration is 0.27 , which indicates that the largest shareholder of the listed company in China's financial industry has a higher shareholding ratio. There are totally 23 samples of the duality of CEO and chairman of the board, with 317 samples separated from each other. Most listed companies are separated by two jobs. The proportion of independent directors is significantly different, the largest is 0.6 , the smallest is 0.17 . The largest board of supervisors has 13 people, the smallest is 2 .

Table 3. Pearson correlation coefficient table

\begin{tabular}{lllllllll}
\hline & $\ln ($ comp $)$ & roe & oc & both & out & ss & $\ln (\operatorname{size})$ & rgr \\
\hline $\ln ($ comp $)$ & 1 & & & & & & & \\
roe & $0.145^{* * *}$ & 1 & & & & & & \\
oc & -0.017 & 0.019 & 1 & & & & & \\
both & $-0.331^{* * *}$ & $-0.147^{* * *}$ & -0.014 & 1 & & & \\
out & -0.065 & -0.015 & 0.077 & -0.023 & 1 & & & \\
ss & $0.260^{* * *}$ & $0.107^{* *}$ & -0.059 & $-0.213^{* * *}$ & -0.031 & 1 & & \\
$\ln ($ size $)$ & $0.400^{* * *}$ & $0.159^{* * *}$ & $0.329^{* * *}$ & $-0.225^{* * *}$ & -0.056 & $0.447^{* * *}$ & 1 & \\
rgr & $0.123^{* *}$ & $0.137^{* *}$ & -0.059 & -0.045 & -0.024 & -0.033 & -0.030 & 1 \\
\hline
\end{tabular}

Note: $* * *$ is significant at 0.01 level, ** indicates significant at 0.05 level, $*$ indicates significant at 0.1 level.

The correlation test of the overall sample was conducted, and the executive pay (common logarithm) has a significant positive correlation with the rate of return on common stockholders' equity, which is consistent with the principal-agent theory. Executive pay (common logarithm) has a significant negative correlation with the combination of two jobs, as opposed to hypothesis 2a. The negative relationship between executive pay (common logarithm) and ownership concentration, the proportion of independent directors is not significant. Executive pay (common logarithm) has a significant positive correlation with the size of the board of supervisors, as opposed to assumption 4a. In conclusion, the hypothesis is tested by Pearson correlation test.

\subsection{Analysis of Empirical Results}

The total samples were analyzed using Stata, and the following regression results are obtained.

Table 4. Equation 1-5 Regression Results

\begin{tabular}{lllllll}
\hline index & \multicolumn{1}{l}{ regression coefficient } & index & regression coefficient & model & $\beta_{1}$ & $\beta_{2}$ \\
\hline roe & $1.63(0.29)^{* * *}$ & ss & $0.01(0.02)$ & Equation 2 & $1.26(0.45)^{* * *}$ & $2.63(1.39)^{*}$ \\
oc & $-0.54(0.32)^{*}$ & size & $0.20(0.05)^{* * *}$ & Equation 3 & $2.66(0.21)^{* * *}$ & $-3.35(0.20)^{* * *}$ \\
both & $-0.15(0.04)^{* * *}$ & rgr & $-0.20(0.04)^{* * *}$ & Equation 4 & $4.26(0.55)^{* * *}$ & $-6.57(1.65)^{* * *}$ \\
out & $-1.48(0.22)^{* * *}$ & _cons & $10.38(1.02)^{* * *}$ & Equation 5 & $0.29(0.28)$ & $0.25(0.07)^{* * *}$ \\
\hline
\end{tabular}

Note. $* *$ is significant at 0.01 level, $* *$ indicates significant at 0.05 level, * indicates significant at 0.1 level.

Hypothesis 1a predicts negative correlation between equity concentration and executive pay. Empirical results validate this hypothesis and are significant at the 0.1 statistical level. Hypothesis $2 \mathrm{a}$ predicts a positive correlation between the duality of CEO and chairman of the board and executive pay, but the empirical results show that they are negatively correlated, and statistically significant at the 0.01 statistical level. Hypothesis $3 \mathrm{a}$ predicts that there is a negative relationship between the proportion of independent directors and executive pay, and the empirical results show that it is statistically significant at the 0.01 statistical level. Hypothesis 4 a predicts a negative correlation between the size of the supervisory board and executive pay. However, the empirical results show positive effects, and there is no statistical significance. Corporate performance has a significant positive impact on executive pay at 0.01 statistical level, and the pay-performance sensitivity is 1.63 , which is consistent with the basic assumptions of principal-agent theory. 
Equation 2 shows that ownership concentration improves the pay-performance sensitivity at the 0.1 statistical level, which is consistent with assumption $1 \mathrm{~b}$. The results of equation 3 show that the duality of CEO and chairman of the board reduces the pay-performance sensitivity at the 0.01 statistical level, which is consistent with assumption $2 \mathrm{~b}$. The results of equation 4 show that the proportion of independent directors reduces the pay-performance sensitivity at the 0.01 statistical level, as opposed to assumption $3 \mathrm{~b}$. The results of equation 5 show that the size of the supervisory board increases the pay-performance sensitivity at the 0.01 statistical level, which is consistent with assumption $4 \mathrm{~b}$.

\section{Conclusions and Suggestions}

\subsection{Research Conclusions}

Based on the data of listed companies in China's financial industry from 2007 to 2015, this paper empirically studies the impact of corporate governance on executive pay and the pay-performance sensitivity, the following conclusions are drawn.

Table 5. Research conclusions

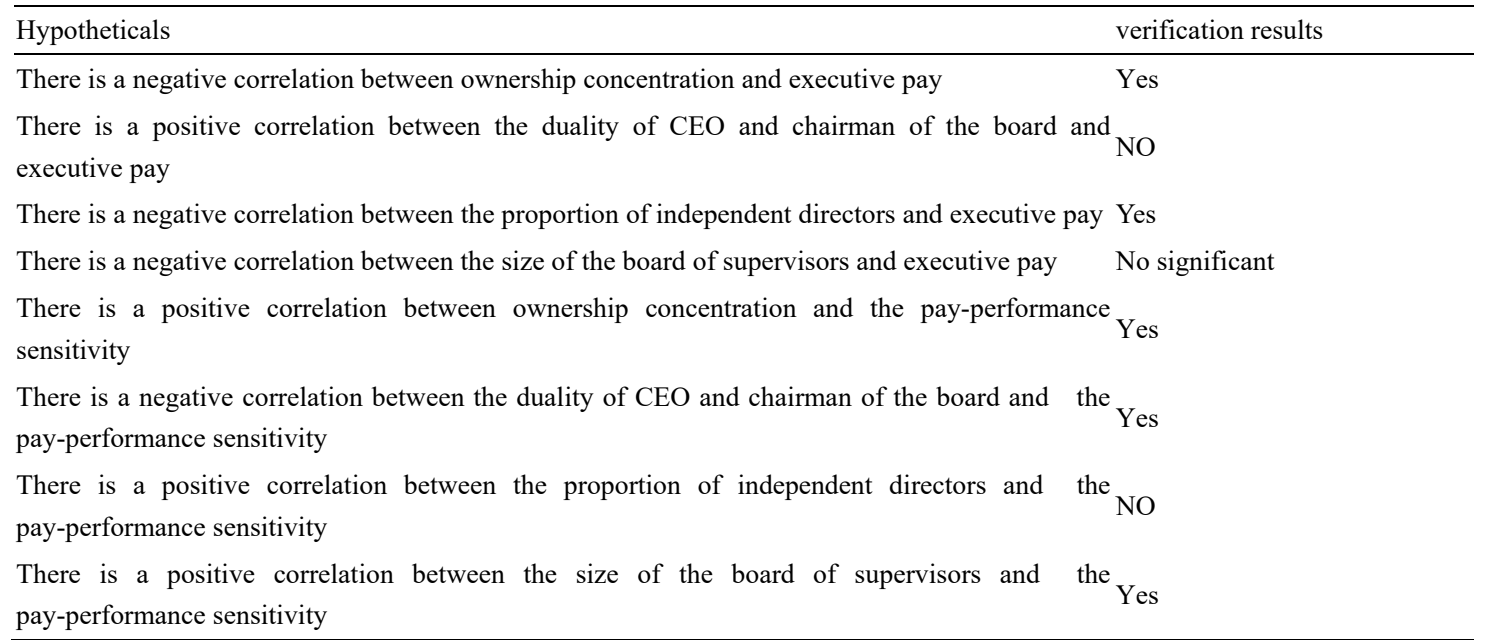

5.1.1 The impact of ownership concentration on executive pay and the pay-performance sensitivity is the same as expected. This shows that when the shareholding structure is dispersed, the lack of supervision by shareholders can easily cause executives to set salaries from their own interests and reduce the sensitivity between pay and performance. When ownership is concentrated, shareholders' supervision and control of remuneration can be enhanced. In the remuneration contract, management can not have decision-making control, so as to reduce the agency costs and prevent management from obtaining excessive remuneration and increase the pay-performance sensitivity.

5.1.2 The impact of the duality of CEO and chairman of the board on executive pay is different from the expectation, and the impact on the pay-performance sensitivity is consistent with the expectation.On the one hand, due to the fact that only 23 data, the sample size is relatively small. On the other hand, financial executives may be paid more attention because of their own higher pay. When the duality of CEO and chairman of the board, they will receive more attention. Based on this, executives may make other concealment means to replace the monetary pay. As the pay-performance sensitivity is not directly disclosed, the monitoring efficiency of the board of directors is reduced when the duality of CEO and chairman of the board. Executives have higher decision-making power, resulting in a decrease in the pay-performance sensitivity.

5.1.3 The proportion of independent directors reduced executive pay but also reduced the pay-performance sensitivity. Due to the existence of independent directors, to a certain extent, the board of supervisors has been strengthened and the remuneration level has been reduced. Descriptive statistics show that the average proportion of independent directors in the financial industry in China is 0.36 , just reached the bottom line of regulatory authorities. The world is generally believed that the independent directors proportion reaches 0.4 to be effective supervision, and compared with developed countries in the West, there is still a great gap. On the other hand, due to the lack of maturity of the independent director system of listed companies in China's financial industry, the independence and impartiality of the appointment of independent directors are not guaranteed. Thus, 
it restricts its promotion effect on the pay-performance sensitivity.

5.1.4 The impact of the board of supervisors size on executive pay is not significant, and the impact on the pay-performance sensitivity is the same as assumptions. As an important part of corporate governance, the board of supervisors can theoretically have a negative impact on executive pay. Previous empirical studies also show that executive pay in the financial industry has nothing to do with the size of the board of supervisors. Maybe in a listed finance company, the function of the board of supervisors is difficult to effectively play, it can not affect the decision-making of executive pay. But the increase in the size of the supervisory board can make the company's governance mechanism more effective in the whole, thus increasing the pay-performance sensitivity.

\subsection{Policy Recommendations}

Based on the inconsistency between the empirical results and the expected hypothesis, we can see the main shortcomings in the governance mechanism of listed companies in the financial industry, and put forward relevant suggestions on the basis of this.

\subsubsection{Improve the Executive Pay Disclosure System}

Since the duality of CEO and chairman of the board of the listed companies in the financial industry will be paid more attention, they should consider the hidden channels in the pay decisions. Therefore, the effective disclosure of executive pay in the financial industry has become the basis for other internal governance mechanisms to play a role, which should be focused and solved first.

(1) Centralized announcement of executive pay information

China can learn from the centralized disclosure model in the United States and concentrate executive pay information in one company document, explaining the basis for the formulation of executive pay, the total amount of funds, and the specific structure. This makes it easier for shareholders, especially for small and medium-sized shareholders who are hard to participate in corporate governance, to understand executive pay, and to make it easier to monitor executive pay.

(3) Establish a pay summary table and improve the pay disclosure structure

The disclosure of executive pay in China requires disclosure of total pay. China should set up a pay summary table, which should not only show the total pay of all executives, but also specify the specific composition of the total payroll. Specific details such as basic pay, bonuses and benefits. This can reduce the existence of the gray zone of executive pay, and show the benefits that executives can obtain from the company in the view of shareholders and the public.

(4) Improve the executive pay disclosure obligations

The legal responsibility for the disclosure of executive pay should be improved. Specifically, the amount of fines can be linked directly to the illegal gains, raising the cost of disclosure of executive pay in listed companies. In addition, a mechanism of accountability that combines civil liability with administrative responsibility can be considered. In the context of serious circumstances, we can consider other penalties.

\subsubsection{Improve the Governance Mechanism of the Board of Supervisors}

The conclusion of the study shows that the board of supervisors has no obvious influence on executive pay, indicating that the function of the board of supervisors of listed companies in China's financial industry is not well played. Therefore, in the governance mechanism of financial companies, we should pay more attention to the governance efficiency of the board of supervisors, find the factors that restrict the functions of the board of supervisors, and improve the governance mechanism of the board of supervisors.

(1) Improve the right of the board of supervisors

Compared with the members of the board of directors, the board of supervisors often fails to obtain first-hand information and has no relevant laws and regulations to safeguard the supervisory board's right to information. The company is not willing to provide all information, and the board of supervisors is not willing to invest enough energy, both the reasons leading to the board of supervisors is difficult to protect the right to information. Therefore, relevant laws and regulations should be made clear that the board of directors should be obliged to provide relevant data and information to the board of supervisors, and ensure the board of supervisors carefully deal with the obligation of information, and exercise their supervisory duties.

(2) Improve the efficiency of the staff supervision system

The efficiency of employee participation system directly affects the effectiveness of the entire supervisory board system. In many cases, employee representatives can not represent the needs of all employees. Therefore, we 
should classify its employees according to the nature of their work and set strict rules on the number of employee supervisors that should be elected for each type of employees. At the same time, when considering the quantity, priority should be given to the general workforce. In addition, when the employee representative as the supervisor, it should restrict the company's right to fire the supervisor of the employee, and make clear the relevant reasons for the dismissal.

(5) Improve the decision-making process of the company

The loss of function of the board of supervisors in our country depends not only on the amount of statutory powers but also on the actual imbalance in the various components of the corporate governance mechanism. To improve the actual status of the board of supervisors, the board of supervisors should be involved in the company's decision-making process so that the board of supervisors can really exert supervisory power over the resolutions of the board of directors. While giving greater power to the board of supervisors, the resolution of the company's board of directors must also be guaranteed.

\subsubsection{Improve the System of Independent Directors}

The conclusion of the research shows that the proportion of independent directors did not improve the pay-performance sensitivity of financial executives, indicating that the system of independent directors in China's financial industry is still deficient. It is suggested to improve the independent director system from the following aspects.

(1) Strengthen the independence of independent directors

As the most essential feature of independent directors, "independence" has greatly affected the effectiveness of independent director system. Therefore, it is necessary to guarantee the independence of independent directors' election and exit. At present, the election of independent directors in our country is mainly controlled by major shareholders. To change this situation, China can draw on the "one person, one vote" rule adopted by Hong Kong on major matters.

(2) Improve the remuneration incentive mechanism of independent directors

Independent directors mainly receive fixed pay, which lacks incentive effect to a certain extent. Independent directors have no incentive to perform their duties. Therefore, on the one hand, it is necessary to increase assessment indicators and incorporate the effects of their supervision into the pay system. On the other hand, stock options are added to the pay system to unify the interests of the independent directors and the company. In addition, the remuneration of independent directors is paid by a third party, and according to the actual meeting time of the independent director, the performance effect will be paid. The payment relationship between the independent directors and the controlling shareholders shall be isolated.

(3) Improve the responsibility commitment and insurance system of independent directors

On the basis of pay incentive, it should also guarantee the risks that independent directors may have in their performance. On the one hand, we can refer to the business judgment rule system in the United States, if the directors in decision making is based on business professional knowledge and experience, whether or not the company profits, the director can escape. On the other hand, we can further promote the directors' liability insurance, and the independent directors make judgments without any worries.

(4) Construction of independent director market

At present, the information of independent directors in our country has great asymmetry. Therefore, it is necessary to build a market capable of quantifying the value of human capital of independent directors and gradually form an independent director market for information sharing and survival of the fittest. On the one hand, it is necessary to intensify the training of the existing exchanges and create some external pressure on the incumbent independent directors by increasing the number of independent directors. On the other hand, there must be a third-party agency to supervise and evaluate independent directors, track the performance of independent directors, and disclose the situation of non-compliance.

\section{References}

Boyd, B. K. (1994). Board control and ceo compensation. Strategic Management Journal, 15(5), 335-344. https:// doi.org/10.1002/smj.4250150502

Conyon, M. J., \& Peck, S. I. (1998). Board control, remuneration committees, and top management compensation. Academy of Management Journal, 41(2), 146-157. https:// doi.org/10.2307/257099

Cordeiro, J., Veliyath, R., \& Eramus, E. (2000). An empirical investigation of the determinants of outside 
director compensation. Corporate Governance An International Review, 8(3), 268-279.

Cronqvist, H., \& Fahlenbrach, R. (2009). Large shareholders and corporate policies. Review of Financial Studies, 22(10), 3941-3976. https://doi.org/10.1093/rfs/hhn093

Cyert, R. M., Kang, S. H., \& Kumar, P. (2002). Corporate governance, takeovers, and top-management compensation: theory and evidence. Management Science, 48(4), 453-469. https://doi.org/10.1287/mnsc.48.4.453.205

Firth, M., Tam, M., \& Tang, M. (1999). The determinants of top management pay. Omega, 27(6), 617-635.

Gao Qi (2015). Ownership Structure, Corporate Performance and Executive Compensation. Friends of Accounting, (7), 41-45. http://dx.chinadoi.cn/10.3969/j.issn.1004-5937.2015.07.011

Gilson, S. C., \& Vetsuypens, M. R. (1993). Ceo compensation in financially distressed firms: An empirical analysis. Journal of Finance, 48(2), 425-458. http://dx.doi.org/10.1111/j.1540-6261.1993.tb04722.x

Han, T. X. (2012). Equity Bargaining, Board Characteristics and Executive Compensation - An Empirical Study of Chinese Listed Companies.

Hartzell, J. C., \& Starks, L. T. (2003). Institutional investors and executive compensation. Journal of Finance, 58(6), 2351-2374. http://dx.doi.org/10.1046/j.1540-6261.2003.00608.x

Huang, J., Jiang, Y. G., \& Tian, B. (2010). An Empirical Study on the Determinants of Executive Compensation in Financial Listed Companies. Economic Issues, (5), 124-129. http://dx.chinadoi.cn/10.3969/j.issn.1006-2912.2010.05.024

Huang, P., \& Chen, L. (2014). Relationship between executive pay, corporate governance and bank performance in listed banks. Modern Commerce and Industry, 26(13), 101-103.

Hwang, B. H., \& Kim, S. (2009). It pays to have friends. Journal of Financial Economics, 93(1), 138-158. http://dx.doi.org/10.1016/j.jfineco.2008.07.005

John, K., \& Qian, Y. (2003). Incentive features in ceo compensation in the banking industry. Social Science Electronic Publishing, 9(1), 109-121.

Khan, R., Dharwadkar, R., \& Brandes, P. (2005). Institutional ownership and ceo compensation: A longitudinal examination. Journal of Business Research, 58(8), 1078-1088. http://dx.doi.org/10.1016/j.jbusres.2004.02.002

Ko, H. C. A., \& Chan, R. S. Y. (2015). How ownership structures affect the relations between product market competition, and pay-performance sensitivity. Social Science Electronic Publishing, 4, 53-67.

Li, W. A., Liu, X. G., Chen, J. H. (2010). Managerial Competence, Reference Point of Corporate Governance and Contract - Theoretical and Empirical Analysis of the Determinants of Executive Compensation of Chinese Listed Companies. Nankai Management Review, 13(2), 4-15. http://dx.chinadoi.cn/10.3969/j.issn.1008-3448.2010.02.002

Liu, M. (2015). Sensitivity analysis of executives' remuneration to corporate performance of listed companies (Doctoral dissertation, Southwest University).

Liu, X., \& Xu, G. W. (2012). Government regulation, management power and rigidity of SOE executives compensation. Economic Science, 34(1), 86-102.

Man, Y. Y., Yang, Y. S., \& Sun, W. (2015). Commercial Banks: A Study on the Relationship between Efficiency, Market Structure and Performance. Journal of Mathematical Statistics and Management, 34(1), $125-141$

Sufang, G. (2011). Human Capital, Organizational Factors and Executive Compensation: A Cross-Level Model. Nankai Management Review, 14(3), 122-131. http://dx.chinadoi.cn/10.3969/j.issn.1008-3448.2011.03.014

Tang, G. Q., \& Hu, M. L. (2012). Research on the Sensitivity of Executive Compensation, Corporate Governance and Compensation Performance. Proceedings of the 2012 Annual Conference of Chinese Society of Accounting.

Wang, C. R., \& Wang, Y. Y. (2015). Market Competition, Management Power and Remuneration-Performance Sensitivity. Dongyue, 36(11), 67-73.

Wu, X. C. (2015). Does Institutional Investors Affect Executive Compensation and Their Private Benefits? -Studies by Institutional Investors with Different Traits. Foreign Economics and Management, 37(8), 
13-29.

Xiong, F. H., Peng, J. (2012). The impact of executive power on executive compensation. Financial Research, (10), 123-128. http://dx.chinadoi.cn/10.3969/j.issn.1000-176X.2012.10.020

Yao, L. S., \& Xu, X. (2012). Research on Executive Compensation Incentives for Innovative Enterprises-Empirical Analysis Based on Innovative Enterprise Data in Central China. Advances in Science and Technology, 29(23), 119-122.

Yermack, D. (1996). Higher market valuation for firms with a small board of directors. Journal of Financial Economics, 40(2), 185-211.

Yuan, C. S., \& Tang, S. L. (2015). External Directors and Executive Pay Incentives: The Regulatory Role of Managers' Markets - Based on the Empirical Study of Private Listed Companies. Journal of Shanxi University of Finance and Economics, 37(5), 84-99.

Zhang, B. W., \& Shi, J. T. (2005). Board Characteristics, Top Management Compensation and Pay Sensitivity An Empirical Analysis of Chinese Listed Companies. Management Science, 18(4), 32-39.

Zhang, X. G., \& Liu, W. (2016). Sensitivity of Executive Compensation Performance of Listed Companies From the Perspective of Corporate Governance.

Zhao, H. W. (2015). Managerial Talent, Power and Executive Compensation - Empirical Evidence from Listed Banks in China. Macroeconomics, (9), 108-116.

Zhou, J. B., \& Sun, J. S. (2003). The Governance Effect of Managers' Equity Incentives - Empirical Evidence from Chinese Listed Companies. Economic Research, (5), 74-82.

\section{Copyrights}

Copyright for this article is retained by the author(s), with first publication rights granted to the journal.

This is an open-access article distributed under the terms and conditions of the Creative Commons Attribution license (http://creativecommons.org/licenses/by/4.0/). 